\title{
$\mathrm{BDNF}, \mathrm{ERK}$ 및 $\mathrm{CREB}$ 경로를 통한 포공영 추출물의 항우울 효과
}

\author{
구필성 ${ }^{1 \#}$, 이지혜 ${ }^{2}$, 최윤희 ${ }^{3}$, 정지욱 $^{2 *}$
}

1 : 경희대학교 한약학과, 2 : 대구한의대학교 바이오산업융합학부, 3 : 원광디지털대학교 한방건강학과

\section{Antidepressant effect of water extract of Taraxacum platycarpum through BDNF, ERK and CREB pathway.}

\author{
Pil Sung Gü ${ }^{1 \#}$ Jihye Lee ${ }^{2}$, Yun Hee Choi ${ }^{3}$, Ji Wook Jung ${ }^{2^{*}}$ \\ 1 : Department of Oriental Pharmaceutical Sceince, Kyung Hee University \\ 2 : Division of Bio-technology and Convergence, Daegu Haany University \\ 3 : Department of Oriental Medicine \& Healthcare, WonKwang Digital University
}

\begin{abstract}
Objectives : Taraxacum platycarpum H. Dahlstedt has been reported to have several biological properties such as skin hydration and antiinflammation. The purpose of this study was to examine the antidepressive effects of water extract of $T$. platycarpum (WTP) on an animal model of depression.

Methods : In the present study, normal ICR mice (4 weeks) were used, and orally administered with WTP (25, 50 and $100 \mathrm{mg} / \mathrm{kg}$ ). Depression-like behavior was monitored the forced swimming test (FST) and tail suspension test (TST) in mice. The locomotor activity was evaluated to eliminate the false-positive activity in the open field test (OFT). Fluoxetine, the selective serotonin reuptake inhibitor, as a positive control was intraperitoneally administered at a dose of $15 \mathrm{mg} / \mathrm{kg}$ at $30 \mathrm{~min}$ before starting the behavioral test. Moreover, we evaluated the effects of WTP on the expression of brain-derived neurotrophic factor (BDNF) and the extracellular signal-regulated kinase (ERK)/ cyclic AMP response-element binding protein (CREB) signaling pathway in the hippocampus using Western blot.

Results : The administration of WTP (50 and $100 \mathrm{mg} / \mathrm{kg}$ ) significantly $(P<0.05$, respectively) reduced the immobility time during FST and TST without accompanying changes in locomotor activity by OFT. Furthermore, WTP at dose of $100 \mathrm{mg} / \mathrm{kg}$ increased the BDNF expression and the phosphorylation of ERK and CREB in the hippocampus region.

Conclusions : These results suggest that WTP has a useful anti-depressant effect through the regulation of BDNF/ERK/CREB signaling pathway.
\end{abstract}

Key words : Taraxacum platycarpum, Antidepression, Forced swimming test, Tail suspension test, Open field test

\section{서 론}

우울증 혹은 우울장애는 흔한 정신 질환 중 하나로 기분 변화, 감소되는 신체적 활동, 무력감, 심리사회적 장애 등을 나타낸다 ${ }^{1)}$. 우울증은 전 세계 1 억 5,000 만 명이 고통 받고 있으며, 세계 보건 기구(WHO)에서는 우울증을 2020년 인류
를 괴롭힐 3대 질병의 하나로 선정한 바 있으며, 미국 국민건 강영양조사(National Health and Nutrition Examination Survey)를 이용하여 우울증 유병률을 조사한 결과, 약 $22 \%$ 가 우울증상을 나타내고 있었으며 ${ }^{2)}$, 우리나라의 경우도 우울 증 유병률이 2006년 2.5\%인데 비하여 2011년 3.2\%로 증가 하였다 ${ }^{3)}$. 또한, 우울증은 인구 통계적으로 2030년까지 전 세

\footnotetext{
*Corresponding author : Ji Wook Jung, Division of Bio-technology and Convergence, Daegu Haany University · Tel : +82-53-819-1337·E-mail : jwjung@dhu.ac.kr

\#First author : Pil Sung Gu, Department of Oriental Pharmaceutical Sceince, Kyung Hee University

- Tel : +82-53-819-1337 · E-mail : sbgps@ naver.com

- Received : 14 May 2015 · Revised : 19 May 2015 · Accepted : 20 May 2015
} 
계적인 장애로 나타날 것이라고 보고되었다 ${ }^{4)}$.

현재 사용되는 항우울제는 크게 삼환계(tricyclin antidepressant, $\mathrm{TCA}$ ), 모노아민 산화효소 억제제(monoamine oxidase inhibitors, $\mathrm{MAOI}$ ), 선택적 세로토닌 재흡수 억제제(selective serotonin reuptake inhibitors, SSRI)로 구분되나 우울증을 겪고 있는 환자의 $40 \%$ 가 이들에 즉각적 반응이 나타나지 않는 것으로 알려져 있고 ${ }^{5)}$, 항우울제가 수면 방해, 나태함, 성 기능 장애 등 다양한 부작용을 나타내며 ${ }^{6)}$, 위약처방 및 다른 항정신성 약품 처방과 유사한 효능을 보인다고 보고되었다 ${ }^{7)}$. 따라서 이 를 개선하기 위해 보다 효과적이고 빠르게 작용하는 항우울제 개발 연구가 필요하다 ${ }^{8)}$.

$\mathrm{BDNF}$ (brain-derived neurotrophic factor)는 신경 성장 촉진인자(nerve growth factor family) 중 하나로 신경 전 달 물질의 조절이나 신경 가소성에 중요한 역할을 하는 것으 로 알려져 있다 ${ }^{9}$. 실제 우울증 환자의 경우 정상인에 비해 혈 청에서 $\mathrm{BDNF}$ 농도가 낮고 ${ }^{10)}$, 항우울제가 $\mathrm{BDNF}$ 의 발현을 증가시킨다고 알려져 있다 ${ }^{11)}$. 또한 $\mathrm{CREB}(\mathrm{cAMP}$ response element-binding protein)는 우울증과 관련된 전사 인자 중 하나로 $\mathrm{BDNF}$ 유전자 발현에 중요한 역할 ${ }^{12)}$ 을 하며 이는 상위 신호전달분자인 ERK(extracellular signal regulated kinase) 에 의해 조절된다 ${ }^{13)}$.

포공영은 다년생 초본인 민들레 (Taraxacum platycarpum H. Dahlstedt)의 전초를 말린 약재(Taraxaci platycarpi Herba)로, 국화과(Compositae)에 속한다. 포공영은 우리나라 에서 식품 또는 약용으로 사용되며 예로부터 간, 위, 급성 기 관지, 부인병 등 염증성 질환에 많이 사용되어 왔다 ${ }^{14)}$. 현재 까지 포공영의 실험연구로는 항산화 효과 ${ }^{15)}$, 항응고 작용 ${ }^{16)}$, 항염증 작용 ${ }^{17)}$ 등이 보고되었다. 그러나 아직까지 포공영의 항우울 효과에 대한 연구는 보고된 바 없다.

따라서 본 연구는 우울증 유발 동물 모델에서 포공영 추출 물의 항우울 효과를 조사하였다. 본 연구에서 강제 수영 실 험, 꼬리 매달기 실험, 과잉 행동 관찰 실험에 의한 포공영 추출물의 우울증 예방 및 치료 효과를 관찰하였으며, 뇌 조직 에서의 $\mathrm{BDNF}, \mathrm{ERK}, \mathrm{CREB}$ 단백질의 발현 변화를 측저아여 매우 유의하고 의미 있는 결과를 얻었기에 보고하는 바이다.

\section{재료 및 방법}

\section{1. 재료}

\section{1)실험동물}

실험동물은 4 주령의 웅성 ICR mice $(23-25 \mathrm{~g})$ 를 대한바 이오링크 (주)(충북, 한국)사에서 공급받은 후 clean cage에 약 7 일간 적응시켜 사용하였으며, 명암주기는 12 시간씩 자 동적으로 조절되는 환경에서 부드러운 깔짚이 깔린 상자에 5 마리씩 사육하였다. 사육실의 온도는 $23 \pm 2{ }^{\circ} \mathrm{C}$ 로 유지되었 고, 습도는 $55 \pm 10 \%$ 로 하였으며, 먹이와 물을 자유롭게 섭 취하도록 하였다. 동물의 관리 및 처치는 대구한의대학교의 동물실험윤리위원회 지침에 따라 수행하였다. 실험 당일 포공 영 추출물 $(25,50$ 및 $100 \mathrm{mg} / \mathrm{kg})$ 은 실험 1시간 전 경구 투 여하였으며, 대조약물로써 항우울제인 fluoxetine $(15 \mathrm{mg} / \mathrm{kg})$ 을 실험 30 분 전 복강 투여하였다.

\section{2) 실험재료}

본 실험에 사용된 포공영은 휴먼허브(경북, 한국)에서 구매 하였고, 약재의 10 배의 증류수를 가하여 $80^{\circ} \mathrm{C}$ 에서 2 시간 열 수 추출하였다. 이를 환류 냉각장치(rotary evaporator)로 감 압 농축하여 얻은 점조상의 추출물을 동결건조(Eyela, model FDU-2000, Tokyo, Japan)하여 실험에 사용하였다(수득율: 15.2\%). Fluoxetine은 시그마 알드리치사(St. Louis, Mo, $\mathrm{USA}$ )에서 구입하여 사용하였다.

\section{2. 방법}

\section{1) 강제 수영 실험}

강제수영실험(Forced swimming test, FST)은 실험동물의 수면 공포를 이용한 항우울효과 측정실험의 전형적인 실험방 법으로 절망행동검사 중 하나이다. 이를 위해 윗면이 개방된 지름 $10 \mathrm{~cm}$, 높이 $25 \mathrm{~cm}$ 투명한 원통 모양의 아크릴 원통에 $20 \mathrm{~cm}$ 의 높이로 수온 $23 \pm 2{ }^{\circ} \mathrm{C}$ 의 물을 채운 뒤 총 6 분간 강제로 수영을 시키며 촬영하였다. 처음 2 분을 제외한 모든 시간 동안 동물이 발버둥치지 않고 물 위에 떠 있는 시간인 부동시간을 행동분석장치인 ethovision system(Noldus, Wageningen, Netherlands)을 이용하여 측정하였다.

\section{2) 꼬리 매달기 실험}

꼬리 매달기 실험(Tail suspension test, TST)은 절망행동 검사의 하나로 검은색 상자 $(30 \times 30 \times 50 \mathrm{~cm})$ 에 실험동물의 꼬리 끝 부분으로부터 약 $1 \mathrm{~cm}$ 떨어진 부위에 테이프를 이용 하여 거꾸로 매달고, 6 분간 부동시간을 ethovision system을 이용하여 측정하였다.

\section{3) 과잉 행동 실험}

과잉 행동 실험(Open field test, $\mathrm{OFT}$ )은 실험동물의 자 발적 활동성을 측정하는 것으로 약물의 항우울 작용이 동물의 활동성에 미치는 영향을 알아보는 실험방법이다. 실험동물을 검은색의 상자 $(25 \times 25 \times 30 \mathrm{~cm})$ 가운데 조심히 넣고 20 분 간 자유롭게 움직이게 한 후 총 보행 거리를 ethovision system을 이용하여 측정하였다.

\section{4) Western blot}

포공영 추출물 투여 후 1 시간 뒤 모든 실험동물을 희생하 고 해마조직을 적출하여 단백질을 분리하였다. 분리된 단백질 을 정량한 후 $12 \%$ polyacrylamide gel에서 전기 영동하여 분리하였으며, polyvinylidene fluoride (PVDF) membrane 을 이용하여 이동시켰다. Menbrane을 $5 \%$ 탈지 분유액(skim milk)으로 1시간 blocking 하고, 1차 항체(BDNF, p-ERK, $\mathrm{ERK}, \mathrm{pCREB}, \mathrm{CREB}, \mathrm{GAPDH})$ 와 함께 $4{ }^{\circ} \mathrm{C}$ 에서 24 시간 동안 반응시켰다. 이를 TBST (Tris-buffered saline with $0.1 \%$ tween 20)를 이용하여 3회 세척하고 2차 항체와 함께 실온에서 1 시간 동안 반응시켰다. 분리된 단백질 관찰은 LAS 4000 mini system(GE Healthcare, VA, USA)을 이용하여 촬영하였다. 


\section{5) 통계 분석}

모든 실험 결과는 평균과 표준오차(S.E.M)로 표시하였고, 각 실험군 간의 통계학적 분석은 일원변량분석(one way-ANOVA) 을 사용하여 유의성을 증명하였으며, 사후 검증은 StudentNewman-Keuls test를 통해 검증하였다. 실험의 통계적 유의성은 $p$ 값이 0.05 이하인 경우에 유의한 것으로 하였다.

\section{결 과}

\section{1. 포공영추출물이 FST에 미치는 효과}

포공영추출물의 항우울 효과를 확인하기 위해 FST를 수행 한 결과, 정상군의 부동시간은 $204.1 \pm 3.7$ 초로 측정되었으 며, 포공영 추출물을 25,50 및 $100 \mathrm{mg} / \mathrm{kg}$ 용량으로 투여 한 군에서는 각각 $215.5 \pm 2.3$ 초, $186.1 \pm 8.5$ 초, $183.8 \pm$ 6.3 초로 측정되어 포공영추출물 50 과 $100 \mathrm{mg} / \mathrm{kg}$ 투여군에 서 정상군에 비해 유의적인 부동시간 감소를 나타내었다. 한 편 양성대조군으로 사용한 fluoxetine 투여군에서도 FST가 $132.0 \pm 14.4$ 초로 측정되어 정상군에 비해 유의성 있게 감소 함을 알 수 있었다(Fig. 1).

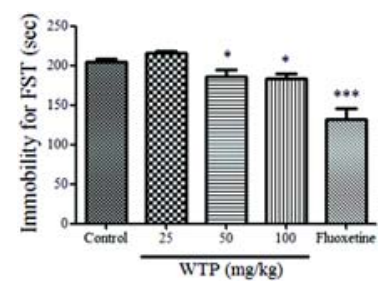

Fig. 1. The effect of WTP (25, 50 and $100 \mathrm{mg} / \mathrm{kg}$, p.o.) or fluoxetine (15 mg/kg i.p) on the duration of immobility in the FST. The duration of immobility was scored during the last $4 \mathrm{~min}$ of a 6 -min test. Values given are means \pm S.E.M, $(N=7)$. $P<0.05$, $P<0.001$ as compared with the control group (one way ANOVA following by Student-Newman-Keuls Method).

\section{2. 포공영추출물이 TST에 미치는 효과}

포공영추출물의 항우울 효과를 확인하기 위해 TST를 수행 한 결과, 정상군의 부동시간은 $205.4 \pm 5.7$ 초, 포공영 추출 물을 25,50 및 $100 \mathrm{mg} / \mathrm{kg}$ 로 투여한 군은 각각 $197.8 \pm$ 13.5 초, $156.7 \pm 12.4$ 초, $159.6 \pm 13.0$ 초로 포공영추출물 50 과 $100 \mathrm{mg} / \mathrm{kg}$ 투여군에서 정상군에 비해 유의적인 부동시간 의 감소를 나타내었다. 또한 fluoxetine 투여군에서도 129.9 \pm 13.1 초로 정상군과 비교하여 유의성 있게 감소하는 것으로 나타났다(Fig. 2).

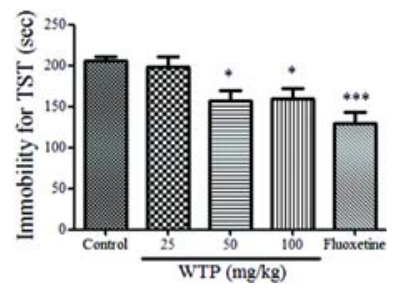

Fig. 2. The effect of WTP $(25,50$ and $100 \mathrm{mg} / \mathrm{kg}$, p.o.) or fluoxetine $(15 \mathrm{mg} / \mathrm{kg}$, i.p.) on the duration of immobility in the TST. The duration of immobility was scored during 6-min test. Values given are means \pm S.E.M, $(\mathrm{N}=7) .{ }^{*} P<0.05,{ }^{* * *} P<0.001$ as compared with the control group (one way ANOVA following by Student-Newman-Keuls Method).

\section{3. 포공영추출물이 OFT에 미치는 효과}

포공영추출물의 항우울 작용이 단순한 활동성의 증가로 인하 여 생기는 지 확인하기 위하여 OFT를 실시하였다. 대조군 및 포공영추출물을 25,50 및 $100 \mathrm{mg} / \mathrm{kg}$ 투여한 군에서의 총 이 동거리를 5 분 간격으로 총 20 분 동안 측정한 결과, 모든 군에 서 자발적 활동성의 통계적 차이가 나타나지 않았다(Table 1).

Table 1. Effects of the aqueous extract of WTP on spontaneous locomotor behavior in mice.

\begin{tabular}{c|c|c|c|c}
\hline Group & Dese $(\mathrm{mg} \mathrm{kg})$ & \multicolumn{3}{|c}{ Total movement distance $(\mathrm{cm})$} \\
\hline & & $5 \mathrm{~min}$ & $10 \mathrm{~min}$ & $20 \mathrm{~min}$ \\
\hline Contol & & $1760.71 \pm 71.16$ & $1534.22 \pm 67.105$ & $4376.789 \pm 137.75$ \\
WTP & 25 & $1739.841 \pm 79.481$ & $1542.205 \pm 83.259$ & $4356.53 \pm 117.288$ \\
& 50 & $1757.792 \pm 97.681$ & $1685.417 \pm 50.655$ & $4506.047 \pm 127.313$ \\
& 100 & $1817.193 \pm 95.604$ & $1555.908 \pm 82.005$ & $4467.532 \pm 210251$ \\
& 15 & $1794.475 \pm 141.51$ & $1626.136 \pm 147.268$ & $4403.64 \pm 244.82$ \\
\hline
\end{tabular}

The effect of WTP (25, 50 and $100 \mathrm{mg} / \mathrm{kg}, \mathrm{p} . \mathrm{o}$ ) or fluoxetine (15 $\mathrm{mg} / \mathrm{kg}$ i.p.) on total movement distance in the OFT. The total movement distance was scored during 20-min test. Values given are means \pm S.E.M, $(\mathrm{N}=7)$.

\section{4. 포공영 추출물의 $\mathrm{BDNF}, \mathrm{ERK}, \mathrm{CREB}$ 발현에}

\section{미치는 효과}

항우울 작용과 관련 있는 대표적 신호전달경로인 $\mathrm{BDNF} /$ $\mathrm{ERK} / \mathrm{CREB}$ 단백질의 발현 변화를 비교하기 위해 Western blot을 실시하였다. 그 결과 해마부위에서 $\mathrm{BDNF}$ 와 $\mathrm{pERK}$, $\mathrm{pCREB}$ 의 발현은 포공영 추출물 $100 \mathrm{mg} / \mathrm{kg}$ 을 투여한 군에 서 정상군에 비해 유의적으로 증가되는 것을 알 수 있었다 (Fig. 3, 4, 5).

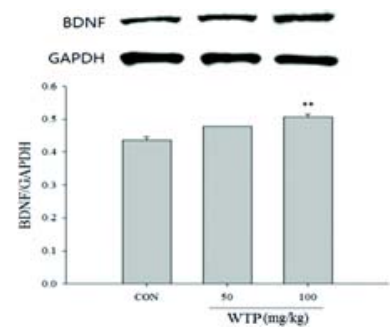

Fig. 3. Western blot analysis of BDNF expression in hippocampus. Band 1: control group; Band 2: WTP (50 mg/kg); Band 3: WTP $(100 \mathrm{mg} / \mathrm{kg})$. Values given are means \pm S.E.M, $(\mathrm{N}=7) .{ }^{* *} P<0.01$ as compared with the control group (one way ANOVA following by Student-Newman-Keuls Method).

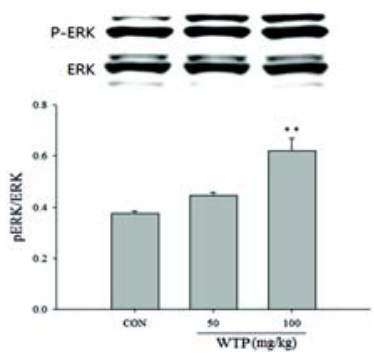

Fig. 4. Western blot analysis of ERK expression in hippocampus. Band 1: control group; Band 2: WTP $(50 \mathrm{mg} / \mathrm{kg})$; Band 3: WTP $(100 \mathrm{mg} / \mathrm{kg})$. Values given are means \pm S.E.M, $(\mathrm{N}=7) .{ }^{* *} P<0.01$ as compared with the control group (one way ANOVA following by Student-Newman-Keuls Method). 


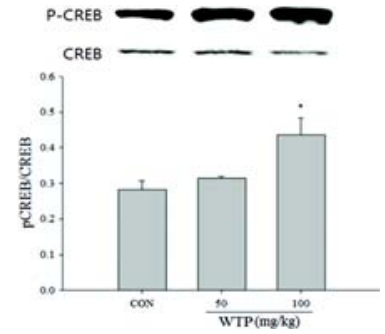

Fig. 5. Western blot analysis of CREB expression in hippocampus. Band 1: control group; Band 2: WTP (50 mg/kg); Band 3: WTP $(100 \mathrm{mg} / \mathrm{kg})$. Values given are means \pm S.E.M, $(\mathrm{N}=7)$. $\quad P<0.05$ as compared with the control group (one way ANOVA following by Student-Newman-Keuls Method).

\section{고 찰}

최근 정신건강 및 신체기능 저하는 우울증, $\mathrm{ADHD}$, 기억 력의 저하, 치매, 불면 등의 원인으로 생각되고 있으며, 특히 우울증에 따른 정신기능의 저하는 사회적인 문제로 대두되고

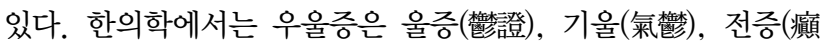
症) 등과 관련이 있으며 이중에서 기울(氣㯺)이 현대 우울증 과 가장 관련이 깊다고 알려져 있다 ${ }^{18)}$. 한약에 대한 항우울증 관련 현대약리연구로 후박 ${ }^{19)}$, 구기자 ${ }^{20)}$, 감초 ${ }^{21)}$ 등의 항우울 효과에 대한 보고가 있다.

본 연구에서는 포공영 추출물의 항우울 효과를 확인하기 위해 마우스에서 사람의 우울증 행동양상과 가장 비슷한 FST 와 TST를 실시하였다 ${ }^{22)}$.

FST는 약물의 항우울 작용을 예측할 수 있는 가장 타당성 있는 방법으로 마우스를 물이 담긴 원통에 빠뜨리면 처음에는 원통형 수조 밖으로 나가려 애를 쓰다가 결국 포기하고 후반부 에 부동자세를 취하는 일종의 행동좌절(behavioral despair) 양상을 보이게 된달. 따라서 시험약물이 효과가 있으면 부 동자세를 취하는 시간이 감소하기 때문에 이를 토대로 약물의 효능을 검정할 수 있게 된다. 본 연구에서 포공영추출물은 50 과 $100 \mathrm{mg} / \mathrm{kg}$ 투여용량에서 정상군에 비해 부동시간이 유의성 있게 감소함을 확인하였다. 한편, TST는 꼬리가 매달 린 쥐는 활동과 부동자세를 교대로 보이는데 이 부동자세를 보이는 시간의 감소 여부를 측정하여 항우울 활성을 검색할 수 있는데, 본 연구에서 포공영 추출물 50 과 $100 \mathrm{mg} / \mathrm{kg}$ 투 여 시 FST에서와 마찬가지로 정상군에 비해 부동시간이 유의 적으로 감소함을 확인하였다. 그러나 locomotor activity 실 험에서는 포공영추출물 투여군과 정상군 모두 총 이동거리의 변화가 없었으며, 이는 포공영추출물이 행동과다의 부작용이 없으면서 항우울 작용을 가지고 있음을 의미한다.

일반적인 항우울제의 투여는 serotonin의 양을 증가시켜 수용체를 활성화시키고 관련 신호전달 단백질들로써 $\mathrm{CREB}$, $\mathrm{ERK}$ 및 $\mathrm{BDNF}$ 의 발현을 증가시키는 것으로 알려져 있달) 따라서 이러한 단백질들은 항우울제제들의 분자적 수준에서의 효과를 확인하는 유용한 표식인자들로 볼 수 있으며, 특히 $\mathrm{BDNF}$ 의 증가는 세로토닌 수용체의 활성화로 해마부위에서 손상된 뇌세포가 다시 회복되는 신경세포 재생성이라는 현상 을 유도함으로써 우울증 환자의 손상된 기억력을 회복시켜 주 는 것으로 알려져 있달) ${ }^{25}$ 본 연구에서 포공영추출물 50 과 $100 \mathrm{mg} / \mathrm{kg}$ 용량의 투여는 해마부위에서의 BDNF 발현과
$\mathrm{ERK}$ 및 $\mathrm{CREB}$ 의 인산화를 증가시켰으며, 특히 $100 \mathrm{mg} / \mathrm{kg}$ 투여군에서 정상군에 비해 유의적인 발현양 증가를 관찰하였다.

현재 우울증 치료제의 주종을 이루고 있는 것은 SSRI 계열의 약물이며, 이보다 한 단계 발전한 것이 serotonin 뿐만 아니라 norepinephrine 및 dopamine의 고갈을 억제하는 serotonin - norepinephrine 재흡수 억제제(serotoninnoradrenergic reuptake inhibitors, SNRI)로 fluoxetine, paroxetine, sertraline 등이 개발되어 임상적 효능을 인정받고 있다. 그 러나 이러한 약물들은 전신 피로감, 성 기능 장애, 불면증과 같은 부작용을 나타낸다고 알려져 있다. 따라서 포공영추출물 과 같이 행동과다의 부작용이 없으면서 효과적인 항우울 예방 및 치료효과를 나타내는 약물발굴이 필요하다.

이상의 결과로부터, 포공영추출물은 FST와 TST 실험에서 정상군에 비해 모두 유의성 있게 항우울 효과를 나타내었으 며, 관련 기전으로써 해마부위에서의 $\mathrm{BDNF}, \mathrm{ERK}$ 및 $\mathrm{CREB}$ 의 발현을 유의적으로 증가시킴을 확인하였다. 향후 포공영의 항우울 효과에 대한 확인을 위해 추가적으로 serotonin 함량 측정, 성분 분석 및 임상연구가 필요할 것으로 생각되며, 다 양한 활성성분에 대한 항우울증 효과에 대한 연구도 진행되어 야 할 것으로 사료된다.

\section{결 론}

마우스에서의 포공영 열수추출물의 우울증 개선효과를 검 증하여 다음과 같은 결론을 얻었다.

1. 강제 수영 실험(FST)에서 포공영추출물 $(50,100 \mathrm{mg} / \mathrm{kg})$ 은 정상군에 비해 부동시간이 현저히 감소하였다.

2. 꼬리 매달기 실험(TST)에서 포공영추출물 $(50,100$ $\mathrm{mg} / \mathrm{kg}$ )은 정상군에 비해 부동시간이 현저히 감소하였다.

3. 과잉 행동 실험 $(\mathrm{OFT})$ 에서 포공영 추출은 정상군과 비슷 한 이동 거리를 나타내었다.

4. 포공영추출물 $(100 \mathrm{mg} / \mathrm{kg})$ 투여에 의해 해마부위 $\mathrm{BDNF}, \mathrm{ERK}, \mathrm{CREB}$ 단백질 발현이 증가되었다.

이상의 결과, 마우스를 이용한 우울증 실험에서 포공영 추 출물은 항우울증 효과를 나타내었으며, 이는 포공영이 우울증 개선 식품 및 의약품 개발 소재로 활용될 수 있음을 의미한다.

\section{감사의 글}

본 연구는 산업통상자원부 지역혁신센터(RIC) 조성사업을 수행하고 있는 대구한의대학교 한방생명자원연구센터(B0009008) 의 지원을 밭아 이루어졌으며 이에 감사드립니다.

\section{References}

1. Murray CJ, Lopez AD. Alternative projections of 
mortality and disability by cause 1990-2020: Global Burden of Disease Study. Lancet. 1997 ; 349(9064) : 1498-504.

2. Shim RS, Baltrus P, Ye J, Rust G. Prevalence, treatment, and control of depressive symptoms in the United States: results from the National Health and Nutrition Examination Survey (NHANES), 2005-2008. J Am Board Fam Med. 2011 ; 24(1) : $33-8$.

3. Cho MJ. The 2011 epidemiological survey of mental disorders among Korean adults. Seoul : Seoul National University College of Medicine. 2011.

4. Mathers CD, Loncar D. Projections of global mortality and burden of disease from 2002 to 2030. PLoS Med. 2006 ; 3(11) : e442.

5. Gareri P, Falconi U, De Fazio P, De Sarro G. Conventional and new antidepressant drugs in the elderly. Prog Neurobiol. 2000 ; 61(4) : 353-96.

6. Bijlsma EY, Chan JS, Olivier B, Veening JG, Millan MJ, Waldinger MD, Oosting RS. Sexual side effects of serotonergic antidepressants: mediated by inhibition of serotonin on central dopamine release?. Pharmacol Biochem Behav. 2014 ; 121 : 88-101.

7. Turner EH, Matthews AM, Linardatos E, Tell RA, Rosenthal R. Selective publication of antidepressant trials and its influence on apparent efficacy. N Engl J Med. 2008 ; 358(3) : 252-60.

8. Cryan JF, Markou A, Lucki I. Assessing antidepressant activity in rodents: recent developments and future needs. Trends Pharmacol Sci. 2002 ; 23(5) : 238-45.

9. Murer MG, Yan Q, Raisman-Vozari R. Brain-derived neurotrophic factor in the control human brain, and in Alzheimer' s disease and Parkinson's disease. Prog Neurobiol. 2001 ; 63(1) : 71-124.

10. Karege F, Perret G, Bondolfi G, Schwald M, Bertschy G, Aubry JM. Decreased serum brain - derived neurotrophic factor levels in major depressed patients. Psychiatry Res. 2002 ; 109(2) : 143-8.

11. Duman RS, Vaidya VA. Molecular and cellular actions of chronic electroconvulsive seizures. J ECT. 1998 ; 14(3) : 181-93.

12. Liebenberg N, Müller HK, Fischer CW, Harvey $\mathrm{BH}$, Brink CB. An inhibitor of cAMP-dependent protein kinase induces behavioral and neurological antidepressant-like effects in rats. Neurosci Lett. 2011 ; 498(2) : 158-61.

13. Qi X, Lin W, Li J, Li H, Wang W. Fluoxetine increases the activity of the ERK-CREB signal system and alleviates the depression-like behavior in rats exposed to chronic forced swim stress. Neurobiol Dis. 2008 ; 31(2) : 278-85.

14. Bae KH, The medicinal plants of Korea. Seoul : Kyu-hak Pub. Co. 2000 : 515-6.
15. Kim HW, Kim BJ, Lim SH, Kim HY, Lee SY, Cho SI, Kim YK. Anti-oxidative effects of taraxaci herba and protective effects on human HaCaT keratinocyte. Kor J Herbol. 2009 ; 24(3) : 103-8.

16. Yun SI, Cho HR, Choi HS. Anticoagulant from Taraxacum platycarpum. Biosci Biotechnol Biochem. 2002 ; 66(9) : 1859-64.

17. Lee DS, Li B, Lee YJ, Chum HJ, Ryu IH, Lee YJ, Chae GU, Kwon YS, Shon JU, Kang HG, Lee SH, An RB, Lee HS. Anti-inflammatory effect of extracts from the roots of Taraxacum coreanum on lipopolysacchaide - induced inflammation in BV2 cells. Kor J Oral Maxillofac Pathol. 2011 ; 35(4) : 231-8

18. Kang HW, Jang HH, Kang IS, Moon HC, Hwang YJ, Lyu YS. A study on the oriental-medical understanding of depression. J Oriental Neuropsychiatry. $2001 ; 12(2): 1-15$.

19. You JY, Woo C, Jeong HR, Choi JH, Lee UJ. Experimental Study on the Antidepressant Effects of Magnolia Officinalis Extracts. Korean J Orient Int Med. 2013 ; 34(3) : 256-66.

20. Lee DK, Gwak DG, Park SD. Antidepressant effect of Licium chinense Mill. and its influence on indoleamine and its metabolite of depression model rats. Herbal formula science. 2003 ; 11(2) : 185-96.

21. Ko SY, Kim DH, Lee TH. Effect of Glycyrrhizae Radix Water Extract on the depression induced by LPS in Rats. Kor J Herbol. 2014 ; 29(5) : 9-16.

22. Su J, Hato-Yamada N, Araki H, Yoshimura H. Test-retest paradigm of the forced swimming test in female mice is not valid for predicting antidepressant - like activity: participation of acetylcholine and sigma-1 receptors. J Pharmacol Sci. 2013 ; 123(3) : 246-55.

23. Yankelevitch-Yahav R, Franko M, Huly A, Doron R. The Forced Swim Test as a Model of Depressive like Behavior. J Vis Exp. 2015 ; 2(97) : doi: 10.3791 / 52587.

24. Takano K, Yamasaki H, Kawabe K, Moriyama M, Nakamura Y. Imipramine induces brain-derived neurotrophic factor mRNA expression in cultured astrocytes. J Pharmacol Sci. 2012 ; 120(3) : 176-86.

25. Gould TD, Manji HK. Signaling networks in the pathophysiology and treatment of mood disorders. J Psychosom Res. 2002 ; 53(2) : 687-97. 